\title{
EMPLOYEE STOCK OWNERSHIP PLANS AND CORPORATE RESTRUCTURING:
}

MYTHS AND REALITIES

Myron S. Scholes

Mark A. Wolfson

Working Paper No. 3094

NATIONAL BUREAU OF ECONOMIC RESEARCH

1050 Massachusetts Avenue

Cambridge, MA 02138

September 1989

We have benefitted from conversations with Alan Auerbach, Jeremy Bulow, and John Shoven. Presented at the Conference on Corporate Governance, Restructuring, and the Market for Corporate Control, New York University, May 22-23, 1989. This paper is part of NBER's research programs in Taxation and Financial Markets and Monetary Economics. Any opinions expressed are those of the authors not those of the National Bureau of Economic Research. 
NBER Working Paper \#3094

September 1989

EMPLOYEE STOCK OWNERSHIP PLANS AND CORPORATE RESTRUCTURING:

MYTHS AND REALITIES

\begin{abstract}
During the first six months of 1989 U.S. corporations acquired over $\$ 19$ billion of their own stock to establish employer stock ownership plans (ESOPs). We evaluate the common claims that there exist unique tax and incentive contracting advantages to establishing ESOPs. Our analysis suggests that, particularly for large firms, where the greatest growth in ESOPs has occurred, the case is very weak for taxes being the primary motivation to establish an ESOP. The case is also weak for employee incentives being the driving force behind their establishment. We conclude that the main motivation for the growth of ESOPs is their anti-takeover characteristics.
\end{abstract}

Myron S. Scholes

Stanford University

Graduate School of Business

Hoover Institution

Stanford, CA 94305
Mark A. Wolfson

Stanford University

Graduate School of Business

Hoover Institution

Stanford, CA 9430 S 
During the first six months of 1989 U.S. corporations acquired over $\$ 19$ billion of their own stock to establish employer stock ownership plans (ESOPs). This compares to only $\$ 5.6$ billion for all of 1988 and less than $\$ 1.5$ billion per year from the passage of the Employee Retirement Security Act in 1974 through 1987.1 Special tax advantages appear to be available to companies using ESOPs. For example, such firms can sometimes deduct dividends paid on ESOP shares as well as benefit from a tax-subsidized borrowing rate on loans used to buy ESOP shares. There are also important nontax considerations such as the claimed incentive advantages of employees owning company stock and the use of ESOPs to defend against hostile tender offers by placing shares in the hands of relatively friendly employees. Our analysis brings into question the notion that ESOPs provide unique tax and incentive advantages. Depending on the benchmark against which they are compared ESOPs can often be beaten along both dimensions.

Our analysis suggests that, particularly for large firms, where the greatest growth in ESOPs has occurred, the case is very weak for taxes being the primary motivation to establish an ESOP. Yet Congress appears to believe that tax benefits explain the growth in popularity of ESOPs over the last few years. In July, 1989, proposed legislation in H.R. 2572 would result in the elimination of both the dividend deduction and the interest subsidy for plans established after July 10, 1989. The case is also weak for employee incentives being the driving force behind the establishment of ESOPs. We conclude that the main motivation for the growth of ESOPs is their anti-takeover characteristics.

The paper proceeds as follows. We begin with an overview of tax and nontax motivations for adopting ESOPs. This is followed by a closer look at the operational characteristics of ESOPs. Our discussion here includes an evaluation of the risk-sharing and incentive features of these plans. We turn next to a closer look at some of their alleged tax advantages. Finally, we present some evidence on the growing importance of ESOPs in the U.S. and conclude with some brief summary remarks.

\section{Overview of Tax and Nontax Motivations for Adopting ESOPs.}

The ESOP is a special type of defined contribution plan (like an individual retirement account, a Keogh account, or a Code Sec. 401(k) pension plan). The corporation makes tax deductible annual contributions to the ESOP and the contributions are generally used to buy company stock or to pay down a loan that that was used to acquire company stock when the program was initiated. Employees are allocated company shares each year tax free and any investment income accumulates tax free within the ESOP. Employees pay tax when they receive dividend distributions on ESOP shares during their

\footnotetext{
${ }^{1}$ Pensions and Investment Age Magazine, July 24, 1989, and Blasi (1988).
} 
working lives or other distributions from the ESOP during retirement or when they otherwise leave the firm.

Unlike most other defined contribution plans, the ESOP is required to invest primarily in the stock of the company establishing the plan, and this is commonly taken to mean that the ESOP must hold at least fifty percent of its assets in the stock of the sponsoring company. Unlike any other defined contribution plan, the ESOP can borrow to buy company stock, to prefund the required number of shares that the firm expects to credit to its employees over the life of the plan. Such plans are called "leveraged ESOPs." As the firm contributes to the ESOP, shares are credited to employees' accounts. Moreover, qualified lenders can exclude $50 \%$ of the interest that they receive on the ESOP loan and the corporation can deduct any dividends that are used to pay down the ESOP loan or are paid directly to employees on their ESOP shares. As we will see, these tax benefits must be balanced against both tax and nontax costs of establishing an ESOP.

ESOPs have become popular in recent years because (1) there are several important tax benefits that are available through an ESOP that are not available through other tax-qualified and nonqualified compensation programs, (2) they can be used to restructure employee work incentives and retirement benefits, and (3) they can be used in corporate finance strategies as substitutes for, or in conjunction with, recapitalizations (changes in corporate capital structures) and leveraged buyouts. For example, ESOPs have been used to sell company divisions to employees. In addition, the deductibility of net operating losses (both existing and so-called "built-in losses") against future taxable income are not restricted if a corporate control change occurs through ownership interests acquired by an ESOP. The 1986 Act restricted the deductibility of such losses upon certain control changes when ownership interests are sold to parties other than ESOPs. Moreover, ESOPs have been used to secure tax deductions on the payment of dividends, to achieve a subsidized borrowing rate on ESOP loans, and to defer the capital gains tax incurred by owners of private companies on the sale of their shares to the ESOP. ESOPs have also been ûsed to allocate interest payments domestically to free up foreign tax credit limitations. The 1986 Act made foreign tax credit limitations a significantly greater concern than it had been previously. The U.S. restricts foreign tax credits to an amount equal to foreign taxable income divided by worldwide taxable income, multiplied by U.S. tax on worldwide taxable income. One way to mitigate this problem is to make foreign-source income, as a fraction of worldwide income, as large as possible. Under Code Sec. 861, interest generated on domestic debt must typically be allocated partially to foreign activities, thereby reducing foreign-source income. It appears possible to allocate $100 \%$ of the interest on certain ESOP debt to domestic income, thereby increasing the allowable foreign tax credits. 
There are other nontax reasons why ESOPs have become popular. An important one is that they have been used effectively to thwart hostile takeover attempts, particularly in the state of Delaware. ${ }^{2}$ In early 1989, Polaroid won an important decision in the Delaware Chancery Court, which upheld Polaroid's issuance of $14 \%$ of its stock to an ESOP prior to the initiation of a hostile tender offer by Shamrock Holdings. The ESOP helped Polaroid's management defeat Shamrock's bid for its stock because employees voted their Polaroid shares with management. Deleware law requires that a firm wait three years after it acquires a $15 \%$ interest in a target before it can merge with the target unless it can secure an $85 \%$ vote of the target's shareholders. ${ }^{3}$ The waiting period can impose substantial costs on the acquiring firm if it had plans to use the assets of the target as collateral for interim or longer-term loans to finance a leveraged buyout. Firm management might establish an ESOP because they believe that employeeshareholders are more likely to vote with them than are outside shareholders. As a result, Polaroid's use of an ESOP as a successful takeover defense stimulated considerable interest in ESOPs.

It is interesting to note that the New York Stock Exchange requires shareholder approval for adoption of an ESOP only when ESOPs acquire more than $18.5 \%$ of employer stock. ${ }^{4}$ In addition, while employees must be granted voting rights in public-company ESOPs, acting on a tender offer is not a voting rights issue, so an ESOP provides a particularly strong tender offer defense. With respect to the Delaware $85 \%$ rule, however, stock held by an ESOP is counted as outstanding shares only if the participants have the right to tender their shares confidentially.

ESOPs are also being used to replace existing defined-benefit pension programs, to replace other types of defined contribution programs, and to replace post-retirement health care programs. In the case of post-retirement health care programs, some corporations are substituting an ESOP for their previous promise to fund the post-retirement health care costs of their employees. ${ }^{5}$ Most post-retirement health-care programs are unfunded and are open-ended as to medical costs. In other words, the corporation makes an unsecured promise to provide health care for employees after they retire, whatever the costs might be. As an alternative, some companies contribute their stock to an ESOP and employees fund their own post-retirement health care costs from their accumulation in the ESOP. By establishing an ESOP, the corporation transfers both the uncertainty of future health costs and the

\footnotetext{
2According to the Wall Street Journal (4/5/89), 179,000 companies are incorporated in Delaware, including $56 \%$ of the Fortune 500 and $45 \%$ of New York Stock Exchange companies.

${ }^{3}$ The three-year waiting period also does not apply if the board of directors and two-thirds of the disinterested stockholders vote in favor of the merger.

${ }^{4}$ Bader and Hourihan (1989b).

${ }^{5}$ Examples include Ralston Purina, Boise Cascade, and Whitman. (Business Week, May 15, 1989).
} 
selection of the level of health care to employees. ${ }^{6}$ But the advance funding of post-retirement benefits through an ESOP (or any other pension fund) reduces the risk that the employer will default on the promise to provide the future benefits.

As pointed out by Freiman (1989), however, advance funding of retiree medical benefits through an ESOP is not necessarily tax advantageous. While the employer secures an immediate tax deduction for the contribution into the pension trust, employees eventually pay tax on withdrawals from the fund. By contrast, pay-as-you-go retiree medical benefit plans allow employees to receive tax-free benefits in retirement, but at the expense of a deferred tax deduction for the employer and the loss of tax-free compounding for advance funding. Section $401(\mathrm{~h})$ plans allow the firm to have the benefits both ways: immediate deduction for advance funding and tax-free compounding of investment returns, along with tax-free benefits to retirees. But it is not yet clear whether these benefits are available to defined contribution pension plans, and no more than $25 \%$ of a pension plan's contributions can be invested in a tax-exempt account to be used to provide for tax-free health care benefits.

That advance funding of retiree medical benefits through an ESOP may be dominated along the tax dimension by other funding alternatives is interesting because it increases the likelihood that nontax factors, such as an enhanced takeover defense, have a first order effect on the decision to fund such benefits through an ESOP. Since tax considerations are reasonably complicated in the pension area, in general, and in the ESOP area in particular, it is important that both independent members of corporate boards, as well as the courts, understand whether there really exist tax benefits for proposed retirement benefit plans, because the adoption of such plans may serve the interests of incumbent management, but not shareholders, along nontax dimensions.

There are many substitute vehicles through which the corporation can achieve the many nontax and tax benefits of ESOPs listed above. However, there are some special tax benefits available to an ESOP that are not available elsewhere. For example, an ESOP can borrow to finance its purchase of company stock at a tax-subsidized rate and deduct the interest on the loan. No other pension plan can do this. Moreover, a corporation can take a deduction for dividends it pays on the stock held in the ESOP if the dividends are paid directly to the employees in cash or if the dividends are used to pay

\footnotetext{
${ }^{6}$ This is not to say that the bargain is one-sided. It may be that the corporation contributes more to the ESOP than the employee gives up in future health-care protection to compensate the employee for bearing the risk of unexpected changes in the cost of health care. On the other hand, employees might manage health care costs more efficiently when they are responsible for the costs.
} 
down part of an ESOP loan. The ability to deduct from corporate taxable income both dividends on ESOP shares and the interest payments on the ESOP loan enables part of corporate income to avoid an entity-level tax, as in $S$ corporations, partnerships, and proprietorships. This has become particularly important with the passage of the 1981 and 1986 Tax Act.

The tax laws in the U.S. have always treated debt (and other claims that give rise to tax deductible payments to the corporation such as obligations to employees, lessors, and suppliers) differently from corporate equities. Whereas interest paid on debt is tax-deductible to corporate borrowers, dividends paid on common and preferred stock are not. In addition, whereas gains and losses on the repurchase of corporate bonds are taxable events to corporate issuers, the same is not true of share repurchases. On the investor side, interest from bonds is taxable as ordinary income whether paid out currently or not, while dividends and changes in the value of stocks are taxable only when realized. Moreover, dividends receive tax-favored treatment to corporate shareholders, and capital gains, besides being granted favorable tax-deferral treatment, have also been taxed at rates well below that of ordinary income to many shareholders.

Since the returns to corporate stock are tax-favored relative to bonds, investors are willing to accept lower pre-tax equity returns, on a risk-adjusted basis, to invest in them. This is similar to what we observe in the market for tax-exempt bonds, where the pre-tax yields are substantially below those of fully-taxable bonds. The same can readily be observed in the market for adjustable-rate preferred stocks, held almost exclusively by corporations for whom the dividend income is largely tax exempt. This reduction in rates exacts an implicit tax from investors. Symmetrically, the rate reduction represents an implicit tax subsidy to issuers of corporate stocks that compensates, at least partially, for the nondeductibility of dividends. ${ }^{7}$

Note that holding everything else constant, increasing the tax rate to investors on income from share ownership reduces the pre-tax wedge between shares and bonds (and therefore reduces the implicit tax subsidy to issuing shares). This makes stock more expensive for corporations to issue relative to bonds. Similarly, increasing corporate tax rates relative to personal tax rates favors corporate debt financing to the extent that such financing moves taxable income from the corporate sector to the noncorporate sector.

Prior to 1981, top marginal tax rates in the corporate sector were well below top marginal personal tax rates. Top personal rates were $70 \%$ from 1965 to 1981 whereas top corporate rates were in the $50 \%$ range. In the two decades preceding 1965, top personal rates were in the $90 \%$ range. During this period of time, top long-term capital gains rates to individuals ranged from $25 \%$ to

\footnotetext{
${ }^{7}$ See Stiglitz (1973), Miller (1977), Auerbach (1983), and Scholes and Wolfson (1987, 1990).
} 
$35 \%$. Such a configuration of tax rates should have caused common stocks to bear substantial implicit taxes, and corporate debt financing might not have been the least bit tax-favored for many corporations during this period.

With the passage of the Economic Recovery Tax Act in 1981, personal tax rates were reduced dramatically while corporate rates were not. But at the same time, capital gains rates were also slashed. Moreover, with interest rates at record levels, the tax advantage of capital gain deferral was particularly high at this time. With top personal tax rates set at a level just above top corporate tax rates, the 1981 Tax Act began to move incentives in the direction of increased corporate borrowing, although this effect was mitigated by the reduction in capital gains tax rates and high interest rates. By 1984, interest rates had subsided dramatically, reducing the tax-sheltered nature of common stocks to some extent, and this further promoted debt financing over equity financing by corporations.

As always, important nontax factors were also bearing on the corporate financing decisions during the early 1980s. In particular, mature corporations were discovering that it was efficient, from a corporate control standpoint, to restructure by buying back equity with the proceeds of debt issues, thereby committing to distribute "free cash flows" to investors through bond interest and principal repayments. ${ }^{8}$ Moreover, increased reliance on strip financing (where institutional investors acquire combinations of junior debt along with equity and/or senior debt, to reduce conflicts of interest among classes of investors) and the rise of active bondholders enabled more debt to be issued without the prospect of incurring excessive deadweight restructuring and bankruptcy costs in the event of default on corporate commitments to creditors. ${ }^{9}$ But it does not seem appropriate to view these developments as being completely independent of the evolution of the tax law. The tax law may well have provided important incentives for the proliferation of these institutional arrangements.

Corporate restructuring took a decided turn in 1984. Net new borrowing by corporations exploded to nearly $\$ 160$ billion a year during 19841986 from $\$ 66$ billion per year during 1978-1983. At the same time there was a quantum leap in the magnitude of both share repurchases ( $\$ 37$ billion per year 1984-1986 versus $\$ 5$ billion per year 1978-1983) and other equity retirements via corporate acquisitions ( $\$ 75$ billion per year 1984-1986, versus $\$ 15$ billion per year $1980-1983) .10$

\footnotetext{
8jensen (1986).

9Jensen (1989).

10 Federal Income Tax Aspects of Corporate Financial Structures (Joint Committce on Taxation), January 18, 1989, Table I-A, I-B on pp. 8-9.
} 
The 1986 Tax Reform Act had an even more dramatic impact on favoring corporate debt financing. Personal rates were reduced to a level well below that on corporations (28\% for wealthy individuals versus $34 \%$ for corporations by 1988) and capital gains tax rates were increased dramatically. This, in conjunction with relatively low interest rates, substantially reduces the implicit tax on shares, thereby making equity financing a particularly expensive way to finance corporate investment.

That debt financing has become more tax-favored with the 1981 and 1986 Tax Acts is closely related to noncorporate forms of organization becoming more tax-favored relative to the corporate form. If all corporate earnings before interest and taxes could be distributed to investors as interest (or interest substitutes), the corporation would essentially be converted to a partnership for tax purposes. There would be no entity-level tax imposed on the corporation, 11 and all owners would pay tax at the personal level on interest income. 12

There are many ways in which the firm can "lever up." One method that has received considerable attention is leveraged buyouts or LBOs. Others include (1) debt-for-equity swaps, (2) dividend-for-debt exchanges, (3) cash redemption of stock financed with debt, (4) deferred compensation plans, (5) partnership arrangements involving deferred payments, and (6) leveraged ESOPs. All of these alternatives are limited in their ability to eliminate the corporate-level tax. Although a 100\%-employee-owned ESOP firm can pay out all of its before-tax income in the form of compensation payments to employees, or dividend payments on ESOP stock or interest payments on ESOP loans, we will see that there are enough tax rule restrictions, natural market frictions, or other nontax costs to prevent the elimination of the entity-level tax.

\section{A Closer Look at the Operational Characteristics of ESOPs}

\section{Contribution Limits}

It is often claimed that an important tax advantage of an ESOP is that the corporation can make tax-deductible contributions to fund it. This advantage, however, is not unique to an ESOP. Contributions to other pension plans are also tax deductible. In fact, so is straight salary.

Because employees can earn the before-tax rate of return on assets invested in a pension plan, it is generally tax-advantageous to provide at least

\footnotetext{
${ }^{11}$ This ignores any corporate "alternative minimum tax" that may be assessed.

${ }^{12}$ See Scholes and Wolfson (1989) for further discussion of these issues.
} 
a portion of compensation in the form of a pension. ${ }^{13}$ An ESOP might be more tax-advantageous than other types of pension plans if the corporation can make more generous contributions to an ESOP than to these alternative pension plans. But this is generally not the case. ESOP contributions are limited, as are other defined contribution plans, to twenty-five percent of compensation. 14

As a tax-qualified pension plan, an ESOP cannot discriminate in favor of highly-compensated employees. ${ }^{15}$ Therefore, it is difficult for senior management to control a large fraction of the shares of an ESOP. Even if the ESOP : Owns the entire company (as is true of AVIS Corp.), senior management might find it difficult to control a large fraction of the company's stock.16

${ }^{13}$ If the before-tax rate of interest is $R_{b}$ and the employee's marginal tax rate today is $t_{p o}$ and on retirement in $n$ years is $t_{p n}$, then for each $\$ 1$ of after-tax income contributed to the pension fund the employce realizes a return of

$$
\frac{\$ 1}{\left(1-t_{p o}\right)}\left(1+R_{b}\right)^{n}\left(1-t_{p n}\right)
$$

If the employee's marginal tax rate is expected to remain constant, she would prefer pension over salary if the before-tax rates of retum on assets invested in the pension plan were greater than the after-tax rates of retum from investing outside the pension plan. Even if the beforetax rates of return were greater in the pension plan, the employee might prefer to invest outside the pension plan if she expected her marginal tax rate to increase in the future or if she had particularly strong demand for current consumption and her borrowing rate was high.

${ }^{14}$ An ESOP is defined in Code Section 4975 as a stock bonus plan (where contributions may be discretionary or contingent on measures of performance, like company profits), or as a combination stock bonus plan and money purchase pension plan (where contributions are neither discretionary nor conditioned on performance measures). If the ESOP is set up as a stock-bonus plan only, annual contributions are limited to $15 \%$ of employee compensation. ESOPs that are a combination of stock bonus and money purchase pension plans face annual contribution limits equal to $25 \%$ of employee compensation.

This amount can not exceed $\$ 30,000$ for any employee and only up to $\$ 200,000$ of compensation is taken into account in determining the percentage allocation to an employce. This $\$ 30,000$ limit will increase over time with inflation adjustments. That is, the maximum contribution must be less than twenty-five percent of $\$ 90,000$, indexed to inflation after 1986 once this amount exceeds $\$ 30,000$. In some cases employees can contribute more to an ESOP than to other defined contribution programs. If less than one-third of the employees participating in the ESOP are highly compensated, the limits can be increased. It is unlikely, however, that lowlycompensated employees would want to contribute more than $25 \%$ of their salary to a defined contribution plan due to a desire for current consumption.

15Indeed, because ESOPs cannot be integrated with social security benefits, while other plans can be, ESOPs face tougher antidiscrimination rules.

${ }^{16} \mathrm{At}$ least seventy percent of ESOP participants must be non-highly compensated employees. The 1986 Tax Act defines "highly compensated employees" as those who own $5 \%$ or more of the company stock, those who eam more than $\$ 75,000$ in compensation from the company, those who eam over $\$ 50,000$ and are in the top twenty percent of employee compensation in the corporation, and officers whose compensation exceeds 150 percent of the contribution limit 
The 1986 Tax Act requires that employee participants in an ESOP be $100 \%$-vested at the end of five years (cliff-vesting) or at least at the rate of $20 \%$ for each year of employment after two years of employment with the firm. A potential nontax cost of these vesting requirements is that with employee turnover, the remaining employees of the firm might receive an unintended benefit. Indeed, remaining employees might have an incentive to promote employee turnover for this reason. An employee can factor expected turnover into his calculations of the amount of current compensation that he is willing to forgo for these expected future benefits. Because of both risk aversion and imperfect information, however, he might be willing to give up far less in current compensation than the cost of these benefits to the employer despite their tax-favored treatment.

Given these anti-discrimination funding requirements, many ESOPs are funded with contribution percentages far less than the allowable $25 \%$ of compensation. For example, Marsh and McAllister (1981) indicate that in over $80 \%$ of the ESOP plans in firms with over 500 employees, contributions to the ESOP amount to $10 \%$ or less of compensation. In a more recent study, Conte and Svejnar (1989) find that ESOP contributions average 10\% of salary and wages.

The primary reason that these contributions are modest relative to contribution limits, despite the tax advantage of increasing contributions and reducing salary, is that the benefits are not valued highly by lower-level employees. The main reason is that they have a relatively strong preference for current over future consumption; they do not wish to save $25 \%$ of their compensation to secure future pension benefits, particularly young employees. If the firm did contribute a large fraction of their compensation into an ESOP, such employees would be forced to borrow on personal account each year to meet their current consumption needs. Given the dead-weight costs of originating and administering such a loan, a lending institution would require that the borrowing rate substantially exceed its lending rate, even if the lender took into account the fact that an employee will realize a future pension benefit that could be used to pay off the loan.

Note that it is not possible to secure a loan with the future proceeds of a pension benefit without disqualifying the pension plan. Moreover, interest incurred on debt to finance personal consumption may be nondeductible. Given these costs, many employees could not borrow at all, and others might feel that they are still better off with current salary than with deferred ESOP income. Although the corporation could still make pension contributions for

specified in the Code $(\$ 45,000$ as of January 1,1987 , or $1.5 \times \$ 30,000)$. Union employees can be excluded from the ESOP (and typically are if the company and the union bargain over contract provisions such as salary, health, and retirement programs). 
these employees, a competitive labor market might force the firm to supplement employee compensation if it is to retain the services of such employees. This extra cost constrains the level of ESOP funding.

Prior to the 1986 Tax Act, the contribution limits were more generous for a defined-benefit pension plan than for an ESOP. Generally, a definedbenefit pension plan provides the participant with a retirement benefit that depends on the level of final salary and/or the number of years of service. Various funding rules allow the corporation to accelerate the funding of its defined-benefit pension fund. This is not possible with a defined contribution plan.

One motivation for overfunding a pension plan is that it enables the corporate sponsor to earn the before-tax rate of return on its investment. The corporation can reduce funding in later years to realize the benefit of overfunding. With the 1986 and 1988 Tax Acts, it became less desirable as well as more difficult to overfund defined-benefit pension plans. Moreover, it now seems more likely that marginal tax rates will increase than decrease. This further reduces the incentive to overfund. All else equal, it is preferable to fund the pension plan when tax rates are high. As a result, defined contribution pension plans have become more competitive with defined benefit pension plans. This might be another reason why firms have established ESOPs.

Some of the advantage of tax-free accumulation in an ESOP is lost, however, since it is necessary for an ESOP to hold at least $50 \%$ of its assets in its company's stock, and common stock is not the most tax-favored security to hold in a pension fund. This may have been particularly so prior to the 1986 Tax Act. At that time, shares might have borne a high implicit tax as we discussed earlier. That is, the before-tax rate of return on shares on a riskadjusted basis might have been far below the risk-adjusted returns on fullytaxable bonds.

With the 1986 Tax Act, $100 \%$ of realized capital gains became taxable. In addition, the corporate dividend-received deduction was reduced from $85 \%$ to $80 \%$ (and reduced further to $70 \%$ in many circumstances following passage of the 1987 Act). As a result, the implicit tax on shares is likely to have fallen and the required risk-adjusted before-tax rate on shares is likely to have increased. This generally means that the tax penalty for holding company stock in the pension plan has become smaller. This is another reason that ESOPs might have become more popular after the 1986 Tax Act. Moreover, contribution limits and anti-discrimination rules became more uniform across different types of pension plans. Because these rules often represent binding constraints, many corporations have substituted defined contribution plans for their defined benefit plans. Defined contribution plans are simpler, 
less costly to operate, and less vulnerable to attack by the firm's many constituents.

The 1986 Tax Act imposed an excise tax of $10 \%$ on the excess assets of a terminated defined-benefit pension plan. This rate was increased to $15 \%$ with the 1988 Tax Act. Prior to 1989, however, corporations were allowed to transfer such excess assets to an ESOP without paying this excise tax. Merrill Lynch, for example, established an ESOP on the termination of its defined benefit pension plan in 1988.17

\section{$\underline{\text { Risk-Sharing Considerations }}$}

ESOPs provide a form of employee ownership in the corporation. This is an important reason why ESOPs have been championed by such members of Congress as retired Senator Long. Employee stock ownership is presumed to align the interests of the employee more closely with the overall goals of the shareholders, relative to a pure salary contract. AVIS, which is $100 \%$ owned by an ESOP, emphasizes employee ownership in advertisements. By implication, customers are meant to feel that AVIS's employee-owners are working harder to meet their needs. ${ }^{18}$

While employee ownership of shares may succeed in promoting a commonality of interests between employees and owners relative to straight salary contracts, it might be more efficient to provide these incentives in alternative ways. Where employees are risk averse relative to shareholders, efficient risk sharing requires that employees bear little risk of change in the value of the firm. But where their activities affect the value of the firm, and these actions are unobservable to shareholders except at prohibitive cost, it is desirable to require employees to bear some risk of changes in the value of the firm for incentive reasons. Risk averse employees will require additional compensation, however, if they are exposed to risk that is beyond their control. Efficient incentive contracting, therefore, requires a judicious trading off of risk sharing and incentives. ${ }^{19}$

It is useful to think of stock prices as an indirect monitor of employee inputs. The value of the firm can be viewed as being determined jointly by employee actions and actions chosen by others such as competitors,

${ }^{17}$ In addition, Figgie International, Transco Energy, ENRON, and Ashland Oil terminated defined benefit pension plans and transferred the surplus to a company-sponsored ESOP.

${ }^{28}$ A vis claims that its customer complaints have dropped by $40 \%$ since its ESOP was formed. It also claims that its costs are now well below those of Hertz, its competitor, although Hertz's costs used to be lower. There is conflicting evidence, however, as to whether ESOP plan adoptions are associated with increased "productivity." For a discussion of the evidence see Blasi (1988), Conte and Svejnar (1989), and Cooper (1989).

${ }_{19}$ Holmstrom (1978) provides a particularly clear statement of the problem, as well as its solution. 
customers, and Nature (that is, random factors). Oftentimes it is possible to devise accounting measures of performance (e.g., divisional profits or physical output measures) that serve as less "noisy" indirect monitors of employee inputs. The reliance on such measures through incentive compensation arrangements is of ten a more efficient way (relative to stockmarket-value-based measures) to align the interests of employees with those of shareholders. More generally, both types of measures (stock-based and accounting-based) contain information that is useful in drawing inferences about the effectiveness of employee performance, but stock-based measures are likely to prove far more "informative" with respect to senior management performance than with respect to lower-level employees. ${ }^{20}$ As a consequence, the implementation of an ESOP may exact a cost along the incentive contracting dimension.

Weirton Steel's $100 \%$ employee-owned ESOP decided to take Weirton public again after a successful revitalization of the company. Part of the reason for the sale of company stock was that many of the vested employees in the ESOP did not want to risk undertaking a $\$ 500$ million expansion of the firm's steel-producing capacity. They preferred a safer position. ${ }^{21}$

It is interesting to note that employee stock ownership was quite common in the 1920s (Patard, 1985). But due to the market crash begun in 1929, $90 \%$ of the stock ownership plans in place before the crash were discontinued by the mid-1930s. Those not terminated restricted participation exclusively to highly-paid employees. This evidence suggests that risksharing considerations are very important.

The tax rules require that employers allow employees to diversify their holdings at the later of age 55 and 10 years of employment. In the first four years following the passage of this milestone, employees must be permitted to diversify up to $25 \%$ of their holdings, and in the fifth year they can invest up to $50 \%$ of their holdings in nonemployer securities.

If employees receive nontraded company stock when they retire or leave the company, they have the right to put the stock back to the company for cash. Depending on the demographics, it might be very costly for the corporation to redeem these shares. Additional funds might have to be raised at a time when it is very costly to do so. Moreover, the release of shares to the employees of a private company might force the corporation to comply with Securities and Exchange Commission reporting requirements. (The threshold is 500 shareholders.) This is also costly.

\footnotetext{
${ }^{20}$ See Lambert and Larcker (1987) for an analysis of stock-based versus accounting-based measures of performance in incentive contracting.

${ }^{21}$ Business Week, January 23, 1989.
} 
Prior to the 1987 Tax Act, many ESOP sponsors provided their employees with a defined-benefit pension plan offset. Examples include Ashland Oil, Bank of New York, and Hartmarx. ${ }^{22}$ In these arrangements, the defined benefit plan might guarantee employees a retirement benefit of say $50 \%$ of their terminal salary during each year of retirement, but distributions to employees would be made from the defined benefit plan only if the ESOP failed to provide at least that same level of benefits. The defined benefit promise serves as a guaranteed floor. This reduces the employee's risk by essentially providing the employee with a put option. Note that shielding employees from risk also means sacrificing incentives. The 1987 Tax Act restricted the use of these defined-benefit-offset provisions.

Firms have discovered other means to reduce the employee's risk of holding company stock in an ESOP. The ESOP can invest up to $50 \%$ of its assets in other than company stock. ${ }^{23}$ The ESOP can also be supplemented with other types of compensation plans to reduce risk. For example, an ESOP might be combined with another defined contribution plan invested entirely in bonds.

Many firms have started to fund the ESOP with convertible voting preferred stock. 24 Holding preferred shares is generally less risky than holding the company's common stock in the ESOP. Given its superior dividend yield, the preferred will tend to sell at a premium over the common (if convertible into at least one share of common) and retain more of its value than the common stock if the value of the company should fall. If the preferred issue represented a substantial majority of the company's stock, however, it would have little protection in the event that the company does poorly.

Moreover, some ESOPs provide employees with a put option. That is, if the preferred stock happens to be selling below the conversion price when the employee retires or leaves the firm, the employee can put the stock back to the company for the conversion price. This put option is valuable to employees and protects them against the risk of a decline in the price of the common stock.

In summary, an ESOP provides a pension savings alternative to more conventional tax-qualified pension funds, one that provides employees with an ownership interest in the firm. Employee ownership might lead the

\footnotetext{
${ }^{22}$ See Forbes (1986).

${ }^{23}$ In a comprehensive survey conducted by the U.S. General Accounting Office in 1986, however, four-fifths of ESOPs invested $75 \%$ or more of their assets in sponsoring company stock.

24 Our analysis of ESOP announcements in the first four months of 1989 from the Dow Jones New Retrieval Service indicates that more than half of all new securities acquired by ESOPs are employer convertible preferred stocks.
} 
firm's "productivity" to improve as employees' interests become better aligned with the firm's other shareholders. But such compensation arrangements may be at the expense of other more efficient forms (ignoring taxes), both for risk-sharing and incentive reasons.

Moreover, there can be severe nontax costs if an ESOP must refinance to repurchase shares from departing employees. Shares that are initially contributed to the trust must eventually be cashed out, and high transaction costs might be incurred to accomplish this task.

With these nontax costs and benefits of establishing an ESOP in mind, let us turn next to the tax benefits. We discuss primarily the tax advantages of a leveraged ESOP and the tax-deductibility of dividends on ESOP shares.

\section{A Closer Look at Tax Advantages of an ESOP}

Prior to the 1986 Tax Act there were two basic types of ESOPs: a tax deduction ESOP (where contributions to the trust give rise to tax deductions) and a tax credit ESOP (where contributions to the trust give rise to tax credits). The tax credit ESOP was eliminated with the 1986 Tax Act. The 1984 Tax Act added significant tax incentives to encourage ESOPs. The 1984 Tax Act provided that (1) shareholders in a closely-held company could obtain a taxfree rollover on the sale of their shares to an ESOP if it attained at least $30 \%$ ownership of the company and if the seller purchased qualified replacement securities such as corporate bonds; (2) the corporation could receive a deduction for dividends paid on ESOP stock, provided that the dividends were paid out currently to employees; and (3) a bank, insurance company, or other commercial lender was permitted to exclude from income $50 \%$ of the interest received on loans to ESOP sponsors, provided that the proceeds of the loan were used to finance the acquisition of employer stock for the ESOP.

The 1986 Tax Act added to these benefits. The 1986 Tax Act provided (1) an estate tax exclusion for $50 \%$ of the proceeds of certain sales of company stock to an ESOP; (2) an expansion of the corporate dividend deduction to include dividends used to repay principal or interest on the loan used to acquire employer securities; (3) a provision allowing mutual funds to be added to the list of lenders eligible to receive the partial interest exclusion on loans to acquire employer securities; and (4) an exemption from the $10 \%$ excise tax on reversions from defined benefit pension plans that are transferred to an ESOP before 1989. The Act repealed the payroll-based ESOP tax credit and required that certain employees be allowed to diversify their accounts. 


\section{The Fifty Percent Interest Exclusion}

Under Code Sec. 133, banks, insurance companies, or regulated investment companies may exclude from gross income 50\% of the interest that they receive on a loan used to buy company stock for an ESOP. There are three types of loans. These include (1) an immediate allocation loan, (2) a leveraged-ESOP loan, and (3) a back-to-back leveraged-ESOP loan. An immediate allocation loan is a loan to the company sponsoring the ESOP. The other two loans are effectively loans to the ESOP itself.

In an immediate allocation loan, the company borrows an amount equal to one-year's contribution to an ESOP and transfers qualifying employer securities to the ESOP. The loan, including any period of refinancing, cannot extend beyond a seven-year term. The transferred securities must be allocated to the individual accounts of employees within one year of the date of the loan (hence the term "immediate allocation").

The immediate allocation loan provides an opportunity for tax arbitrage in appropriate circumstances. To illustrate this, note that if lending markets are competitive and if there are no special costs associated with ESOP loans, the risk-adjusted before-tax rate of return on the loan, $\mathrm{R}_{\mathrm{I}}$, will be given by the following relation:

$$
\begin{gathered}
R_{I}\left(1-.5 t_{c}\right)=R_{b}\left(1-t_{c}\right) \\
\text { or } R_{I}=R_{b}\left(1-t_{c}\right) /\left(1-.5 t_{c}\right),
\end{gathered}
$$

where $\mathrm{t}_{\mathrm{C}}=$ corporate marginal tax rate;

$\mathrm{R}_{\mathrm{b}}=$ the before-tax risk-adjusted return on fully-taxable bonds; and

$\mathrm{RI}=$ the required before-tax rate of return on the ESOP loan.

So if corporate marginal tax rates are $34 \%$, this implies that the rate of interest on the immediate allocation loan will be $79.5 \%$ of the fully-taxable rate. 25 Empirical evidence suggests that ESOP loan rates are set between $80 \%$

\footnotetext{
25Insurance companies are required to include $15 \%$ of any tax-exempt interest that they receive in taxable income. As a result, the insurance company would require a rate of interest that is $82 \%$ of the fully-taxable rate ( or $\mathrm{R}_{\mathrm{I}}=.66 \mathrm{R}_{\mathrm{b}} /(1-1.15 \times .5 \times .34)$ ). See Bader and Hourihan (1989a). Mutual funds can create dual-class ownership, where one class receives the partially tax-exempt interest and other shareholders receive fully-taxable interest. As a result, corporations with a $34 \%$ marginal tax rate or high marginal-tax-rate qualified noncorporate taxpayers might be the marginal holders of the tax-exempt piece.
} 
and $90 \%$ of the fully-taxable rate, with securitized loans priced at roughly $75 \%$ of the prime rate. ${ }^{26}$

Assume for the moment that the corporation already has an ESOP and has determined the magnitude of this year's required contribution of stock. If the firm were to finance the contribution to the ESOP with an immediate allocation loan, the corporation's after-tax interest cost would be $R_{I}\left(1-t_{c}\right)$ or approximately $80 \%$ of the after-tax cost of an ordinary loan for a $34 \%$ corporation that captures most of the tax benefits of the $50 \%$ interest exclusion via an interest rate reduction. If the corporation were otherwise planning to repurchase its stock using its internal cash flow, it would be tax-advantageous to use the proceeds of the immediate allocation loan to buy shares in the open market to contribute to the ESOP and use its internal cash flow to pay back some company debt.

Moreover, if the company currently contributes stock to a defined contribution pension plan other than an ESOP, it would be tax-advantageous for the company to switch to an ESOP. The seven-year immediate allocation loan is quite valuable. For example, if the before-tax bond rate is equal to $10 \%$, the immediate allocation loan would have a before-tax rate of interest of $8 \%$ and an after-tax rate of interest of $5.28 \%$ (or $8 \%(1-34 \%)$ ). If the corporation's ordinary borrowing rate is $10 \%$, its after-tax cost is $6.6 \%$. The immediate allocation loan offers an after-tax savings of $1.32 \%$ per year for a maximum of seven years. The present value of this benefit at a discount rate of $6.6 \%$ is $7.3 \%$ of the principal amount of the loan. 27

While the immediate allocation loan is a loan for only one year's contribution to the ESOP, it is also possible for the ESOP to borrow to acquire stock that will fund the contributions to the pension fund for many years. This is called a leveraged ESOP. The ESOP borrows enough such that the loan proceeds can buy sufficient stock to fund, say, the next fifteen annual contributions. As with immediate allocation loans, qualified lenders can

\footnotetext{
26See Kaplan (1989), Merrill Lynch (1988), Shearman and Sterling (1989), and Shackleford (1988). Care must be exercised in gathering evidence on these rates. Because of the $50 \%$ exclusion, it pays to set a high rate on an ESOP loan and a lower rate on fully-taxable loans. The tax laws impose restraints on this, but there is still room to set rates opportunistically. To test this, loans should be separated into two piles: those where the lender has no other business dealings with the buyer and those where the lender also engages in non-ESOP transactions with the borrower. Care must also be exercised to determine the correct risk adjustment to be made in comparing interest rates across loans.

${ }^{27}$ The government also subsidizes any deadweight costs that are uniquely incurred to underwrite the ESOP loan. The lender deducts its costs to process and underwrite the loan while the borrower pays less than $100 \%$ of the these costs through the intercst break. Further, the $50 \%$ interest exclusion encourages the bundling of other services with the loan to secure a $50 \%$ income exclusion on revenues generated from these other services.
} 
exclude from taxable income $50 \%$ of the interest received on the leveraged ESOP loan.

If a leveraged ESOP borrows and buys company stock, the stock is placed in a so-called "suspense account." Each year as the corporation makes tax-deductible cash contributions to its ESOP, stock is released from the suspense account and allocated to the accounts of the participants. The contribution is then used to pay down the loan. The corporation can deduct up to $25 \%$ of compensation each year, the same as for an unleveraged ESOP. It also can deduct the interest payments that it contributes to the ESOP to pay the interest on the ESOP loan. Also any dividends that are paid on the stock allocated to the participants or on the unallocated shares held in the suspense account can be used to pay down the loan. These dividends are tax deductible to the corporation.

It is often claimed that a leveraged ESOP is tax-advantageous because the corporation can make tax-deductible principal repayments on its ESOP loans. As we have already noted, however, all compensation payments are tax-deductible to the corporation. However, the 50\% exclusion of interest on the loan and the deductibility of certain dividends are tax-advantageous. These options are not available with other plans.

It is harder to quantify whether the corporation should use an immediate allocation loan or a leveraged-ESOP structure. The term of the leveraged-ESOP loan can extend for as many years as the company wishes to precommit to contribute stock to its ESOP. ${ }^{28}$ It must, however, pay down the ESOP loan uniformly over its life. The immediate allocation loan can only extend for a period of seven years. But it can be a term loan in which all principal is repaid at maturity. Each year the corporation can issue another immediate allocation loan to fund that year's contribution to its ESOP. Although a leveraged ESOP loan is initially a much larger loan than an immediate allocation loan, the size of the loan falls each year as the principal on the note is reduced.

Another advantage of immediate allocation loans over leveraged ESOP loans is that where share prices are increasing over time, immediate allocation loans yield larger tax deductions for a given cost of buying shares deposited into the ESOP. The reason for this is that in a leveraged ESOP, tax deductions are based on the value of the stock at the time the shares are first acquired, whereas in the immediate allocation plan, the deductions are based

\footnotetext{
${ }^{28}$ Although the term of the ESOP debt is limited by the number of years to which the employer will commit to making ESOP contributions, the maturity of the loan is restricted to ten years if the employer uses the "principal method" of allocation to release shares from the suspense account. Generally, the proportional method is used, wherein shares are released from the suspense account in proportion to interest and principal that is paid on the loan.
} 
on share prices at the time the shares are allocated to participant accounts. ${ }^{29}$ Depending on the length and size of the ESOP program, the present value of the tax benefits could be greater with an immediate allocation loan than with a leveraged-ESOP loan.

If future legislation were to limit the tax benefits of ESOP programs, the long-term loan might prove more or less attractive than the immediate allocation loan depending upon the particular "grandfather" provisions included in the legislation. It is interesting to note that many of ESOP loans are written with provisions that guarantee the lender a benchmark after-tax rate of return that floats with the return on a taxable loan of comparable risk (e.g., Treasury bill plus some fixed number of basis points). The rate of interest on the loan changes if statutory tax rates change or if the percentage of interest that is tax-exempt were to change. The corporation could be at a definite disadvantage if Congress were to limit tax-deductible contributions to defined contribution plans and, as a result, prevent the corporation from making tax-deductible contributions to its pension plan of sufficient size to pay down the loan.

The back-to-back loan is very similar to the leveraged ESOP loan. In this case, the corporation borrow's to purchase company stock and relends the same amount to its ESOP. The ESOP buys the company's stock with the proceeds. There are two separate loans, one from the qualifying institution to the corporation, and one from the corporation to the ESOP trust. To qualify for the same tax treatment as the leveraged-ESOP loan, the repayment schedule and the interest rate must be essentially identical. If not, the back-toback loan is limited to a term of seven years. Moreover, leveraged-ESOP loans cannot be accelerated in the case of a default. As a result, many lenders prefer back-to-back loans. Also, the lender might feel more secure dealing with a corporation than with a trusteed pension plan. A pension plan never borrows except to finance a leveraged ESOP. The body of law concerning the property rights of the parties to leveraged-ESOP transactions is not well established.

The leveraged-ESOP structure has been used in a number of leveragedbuyout transactions. It has also been used to accomplish such corporate finance objectives as (1) implementing a share repurchase program, (2) selling a division to employees, (3) placing a large block of the company's stock in employee (friendly) hands, and (4) taking a company private. However, there are several problems with this structure. The company must project future employee contributions. Overestimating the required payments would cause the employer to borrow an amount in excess of the actual annual requirements. Prepaying this excess amount of debt would result in the

${ }^{29}$ See Freiman (1989) for a more extensive analysis of this issue. 
allocation of shares to the participants' accounts. Employees could benefit at the expense of the other shareholders.

\section{The Deduction of Dividend Payments}

Under Code Sec. 404(k), the corporation can deduct dividends to an ESOP if (1) the dividends are paid in cash directly to ESOP participants, (2) the dividends are paid to the ESOP and it distributes them to participants within 90 days of the close of the plan year, or (3) the dividends on ESOP stock (whether in the suspense account or allocated to participants) are used to make payments on an ESOP loan as described in Code Sec. 404(a)(9). The ability to take a deduction for dividends used to make payments on an ESOP loan was introduced by the 1986 Tax Act.

The deductibility of dividends eliminates the entity-level tax on part of the corporate income. In the extreme, if all the shares of a corporation were owned by its employees, and the corporation paid out tax-deductible dividends equal to its pre-dividend taxable income, all of the corporation's income would be taxed only once at the individual shareholder level. It is not entirely clear, however, that this should be taken too literally. The 1984 Act contained a provision empowering the Treasury to disallow dividend deductions to the extent they are deemed to "contribute to tax avoidance." Presumably this would be invoked if profitable businesses sought to distribute all profits as tax-deductible dividends. On the other hand, the provision may simply be a "paper tiger."

To see that dividends which are deductible to the corporation and paid on ESOP shares to participants convert the corporate tax to a single level of taxation under most circumstances, assume that the corporation is currently contributing \$10 million to an ESOP at the end of each year. Further assume that this is less than the maximum contribution permitted of $25 \%$ of compensation. ${ }^{30}$ Assume that the employer pays a dividend of $\$ 3$ million at year end on the ESOP shares and that this dividend is paid directly to the participants. Now suppose the corporation alters its policy by contributing $\$ 13$ million to the ESOP instead of the usual $\$ 10$ million and by reducing employee salary by $\$ 3$ million. As a result, while salary is reduced by $\$ 3$ million, employees receive $\$ 3$ million in dividends from the ESOP. Employee pension accounts grow in value by the return on the pension assets less $\$ 3$ million distributed as a dividend, but the corporation contributes an additional $\$ 3$ million to the ESOP. So the accumulation in employee ESOP accounts, as well as their current compensation (salary plus dividends), is unaffected by this change in policy. From the corporation's viewpoint, the before-tax cash outflows are also exactly the same whether the corporation

\footnotetext{
${ }^{30}$ As discussed earlier, very few plans actually face binding constraints on the contribution limit. This is particularly so for public companies.
} 
contributes to a qualified stock-bonus plan and pays a dividend on these shares or it contributes to an ESOP.

For example, assume that employee salaries, before the ESOP plan was adopted, totaled $\$ 50$ million. If $\$ 10$ million was also contributed to a stock bonus plan and $\$ 3$ million in dividends were paid, the total pretax cash outflows would be $\$ 63$ million. Under the ESOP plan, with dividends paid currently to employees, cash outflows would be $\$ 47$ million in salary, $\$ 13$ million in contribution to the ESOP, and $\$ 3$ million in dividends on the ESOP shares. The total of $\$ 63$ million is exactly the same as if the corporation contributed to a stock-bonus plan. After tax, however, the corporation is better off because it secures a tax deduction for $\$ 3$ million of dividends. So if corporate tax rates are $34 \%$, the corporation can eliminate just over $\$ 1$ million in tax per year from the dividends paid to employees through securities that they hold in their ESOP accounts. ${ }^{31}$ In effect, as employees accumulate securities in their ESOP accounts, they receive tax-deductible dividends from the corporation that convert income that would have been taxed at the corporate level, and then again at the personal level, to income that is taxed only once at the personal level.

Notice, however, that this plan works only if employees are not up against the $25 \%$-of-compensation contribution limits. If the corporation is already funding contributions to an ESOP to the maximum allowed under the tax rules, it could not increase its funding and reduce current compensation as assumed in the analysis above unless a leveraged ESOP structure is used and dividends are used to pay down ESOP loans.

Corporate deductions can also be secured when dividends are used to make payments on an ESOP loan. But, contrary to popular belief, there is no tax advantage to using dividends to make payments on a leveraged loan. To see this, note that to secure a tax deduction for the dividends, participants must be allocated shares in the ESOP equal in dollar value to the dividends used to pay down the loan. Since employees are allocated shares equal to their share of the dividends, the firm should be able to cut back other pension contributions in the same amount, leaving employees unaffected. As a result, the corporation's taxable income is also unaffected, so the deductibility of dividends does not reduce the corporate-level tax in this case.

The one case in which dividend deductibility on ESOP loans is advantageous is where employees want to add to their pension savings beyond the $25 \%$-of-compensation limits. They are permitted to exceed the limits by using dividends to make payments on the ESOP loan. On the other hand, except in small, privately-held corporations, it is very uncommon that

\footnotetext{
${ }^{31}$ Moreover, the firm and certain employees can avoid paying some social sccurity taxes on their reduced salary.
} 
employees wish to invest so heavily in pension savings, especially in a plan that is so poorly diversified.

ESOPs Financed with Equity Providing Dividend Pass-through versus Debt-financed Pension Plans Investing in Debt Securities

In the preceding discussion, we demonstrated that if for nontax reasons employee stock were held in the pension fund, an ESOP could profitably be used to effect tax savings. In this section we demonstrate that, ignoring the advantage of the 50\% interest exemption on qualified ESOP loans, as well as other less important special tax features, ESOPs are really dominated by other pension funds that avoid investing in employer equity securities. We further argue that in many relevant cases, the interest rate subsidy resulting from the $50 \%$ exclusion of interest income roughly compensates for the tax disadvantage of ESOPs. So, in the end, whether ESOPs are desirable, particularly for publicly-traded companies, depends largely on the nontax benefits of employee ownership of employer shares.

To establish that ESOPs with dividend pass-through to employees are weakly dominated by debt-financed defined contribution pension plans, we proceed in stages. We begin by analyzing the after-tax cash flows to employees and employers when $\$ 1$ is contributed into a pension plan, financed by debt bearing interest at rate $R_{b}$. The pension plan in turn invests in interestbearing securities yielding rate $\mathrm{R}_{\mathrm{b}}$ per year. The tax rates of the employer and the employee are $t_{c}$ and $t_{p}$, respectively.

\section{Case I: Debt-financed Pension Fund}

\section{Time Period}

$\begin{array}{ll}\frac{\text { Time Period }}{\text { Today }} & \frac{\text { Annually Through }}{\text { Retirement }}\end{array} \frac{\text { At Retirement }}{\text { (time } 0)} \quad$

Cash Flow to:

$\begin{array}{lc}\text { Employer } & +\mathrm{t}_{\mathrm{C}} \\ \text { Employee } & 0\end{array}$

$-R_{b}\left(1-t_{c}\right)$
0

$-1$

$+\left(1+R_{b}\right)^{n}\left(1-t_{p}\right)$

At time 0 , the employer borrows $\$ 1$ and deposits it into the pension plan, a net cash flow of $\$ 0$. A tax deduction of $\$ 1$ for the contribution to the pension fund, however, yields a tax savings of $t_{C}$ for the employer, so total cash flow is $+t_{c}$. Each year thereafter, through retirement, the employer pays out interest of $\mathrm{Rb}_{\mathrm{b}}$, which is tax deductible at rate $t_{c}$. Finally, at retirement, in $n$ years, the employer repays the $\$ 1$ principal amount of the loan and the 
employee cashes out the pension. By this time, the pension assets have grown in value to $\left(1+R_{b}\right)^{n}$, and the employee is taxed on this amount at rate tp.

Next, compare these cash flows to those that result from the employer forming an ESOP, financing the $\$ 1$ contribution to the trust with a preferred stock paying a dividend of $\mathrm{R}_{b}$ per period. Dividends are reinvested in the trust rather than paid out each year to the employee.

Case II: Preferred Stock-financed ESOP with Dividends Reinvested in the Pension Plan

\section{Time Period}

$\frac{\text { Today }}{\text { (time 0) }} \quad \frac{\text { Annually Through }}{\underline{\text { Retirement }}} \quad \frac{\text { At Retirement }}{\text { (n years) }}$

Cash Flow to:

$\begin{array}{lccc}\text { Employer } & +t_{c} & -R_{b} & -1 \\ \text { Employee } & 0 & 0 & +\left(1+R_{b}\right)^{n}\left(1-t_{p}\right)\end{array}$

Except for the annual cash outflow for the employer to service the security issued to fund the pension plan, cash flows are identical to those for the debt-financed pension fund. Here, however, the dividend payments are nondeductible, so while the employee is indifferent across the alternatives, the employer is worse off by $R_{b} t_{c}$ per period. Note that $R_{b} t_{c}$ is simply the tax shield from interest deductibility available in Case I but not Case II.

Finally, consider the case of an ESOP financed with employer preferred stock, but where these dividends are paid out to the employee each period.

Case III: Preferred Stock-financed ESOP with Dividends Passed Through to Employees

\section{Time Period}

$\frac{\text { Today }}{\text { (time 0) }} \quad \frac{\text { Annually Trough }}{\underline{\text { Retirement }}} \quad \frac{\text { At Retirement }}{\text { (n years) }}$

Cash Flow to:
Employer
$+t_{c}$
$-R_{b}\left(1-t_{c}\right)$
$-1$
Employee
0
$+R_{b}\left(1-t_{p}\right)$
$+1-t p$ 
Note that while the cash flows to the employer in this case coincide with those in Case I (debt-financed pension plan), those for the employee are not directly comparable since both interim and terminal cash flows are different. To make them comparable, suppose the employer reduces the employee's salary by $\mathrm{R}_{b}$ per period, contributing this amount to a non-ESOP pension plan that earns interest at rate $R_{b}$ per period. In this case, the interim cash flows to the employee will be \$0, just as in Case I.

To see how the ESOP with dividend pass-through compares with a debt-financed pension, then, we need only compare the terminal after-tax cash flow to the employee in this case with that in Case I (since all other cash flows to both parties now coincide). The supplementary pension plan for the employee accumulates to the future value of an annuity of $R_{b}$ dollars for $n$ periods with interest at rate $\mathrm{R}_{b}$ per period. This is equal to:

$$
R_{b}\left[\left(1+R_{b}\right)^{n}-1\right] / R_{b} \text { or }\left(1+R_{b}\right)^{n}-1
$$

This is fully taxable at rate $t p$, so the after-tax amount is:

$$
\left(1+R_{b}\right)^{n}\left(1-t_{p}\right)-\left(1-t_{p}\right)
$$

We can now add this supplementary pension amount to the 1 - tp available from the ESOP, and we are left with

$$
\left(1+R_{b}\right)^{n}\left(1-t_{p}\right)
$$

This is exactly the same terminal amount the employee receives in Case I, the debt-financed pension plan.

While a comparison of Cases I and III makes it appear as though the ESOP (with dividend pass-through) is equivalent to the debt-financed nonESOP pension plan, this is only because we have allowed the ESOP to invest in preferred shares that have no equity-like features to them. That is, the dividend yield is the full interest rate, and there is no capital gain component to it. But in fact, the ESOP assets must be invested primarily (that is, at least $50 \%$ ) in employer common stock or convertible preferred stock, and these securities almost always have an expected capital appreciation component. ${ }^{32}$

\footnotetext{
${ }^{32}$ The preferred stock must be convertible into the common stock of the company at a "reasonable" conversion price, which has not yet been clearly defined. The firm must not be permitted to call the preferred, or if it can, the preferred must be convertible prior to the call. It must be convertible into a readily tradeable stock if traded on a securities market. If no such stock exists, the preferred must be convertible into the issue that contains the most voting and dividend rights among all outstanding shares. This last condition might be difficult to satisfy in certain cases. For example, if an ESOP is formed in conjunction with a leveraged buyout, the
} 
Case II can be viewed as a case in which the ESOP is financed with nondividend-paying common stock. The interim cash outflow of $\mathrm{R}_{b}$ can be interpreted as the non-deductible sinking fund contribution required to cover the appreciation in the share of stock that the employer will have to repurchase from the employee at time $n$.

More typically, the employer securities contributed to the ESOP will have a dividend yield somewhere in between those for Cases II and III. In such circumstances, the employer will be worse off, relative to a non-ESOP pension plan, by the value of a tax deduction on the difference between the current yield on the ESOP securities and the interest rate on debt. In this light, one might view the availability of the tax exemption to qualified ESOP lenders of half the interest income on ESOP loans as a way of neutralizing the disadvantage demonstrated above. The analysis also helps to explain why high dividend-yielding convertible preferred stocks have become so popular as an investment in ESOPs. ${ }^{33}$

If the $50 \%$ interest income exemption roughly compensates for the reduced deductibility of the employer cost to service the securities issued to fund the ESOP, then the differences between ESOPs and other pension plans becomes restricted largely to the nontax dimension. In particular, with more employer securities in the ESOP, work incentives are clearly affected, and voting control is clearly enhanced, thereby providing a superior takeover defense (or more pejoratively, enhanced management entrenchment).

\section{Evidence on the Growing Importance of ESOPs in the U.S. Economy}

It is unfortunate that the most complete survey available of the prominent features of ESOPs goes only through $1984 .^{34}$ The Deficit Reduction Act of 1984 and the Tax Reform Act of 1986 had dramatic effects on incentives to utilize these trusts to take advantage of the tax-favored leveraging opportunities and dividend deductibility. Table 2 reveals that at

structure of the leveraged buyout might be such that it is difficult to know which security has the greatest voting and dividend rights.

${ }^{33}$ Other reasons for the popularity of high dividend-yielding convertible preferred stock include (1) reduced investment risk for employees, although this presumably comes at the expense of reduced incentives, and (2) leveraging of voting-rights in presumably friendly hands (a defense weapon).

${ }^{34}$ United States General Accounting Office (1986). 
Table 2 Growth in the Number of ESOP Plans and Number of Employees Covered

\begin{tabular}{ccc}
\hline Year & Number of Plans $^{\mathrm{a}}$ & Number of Employees Covered $^{\mathrm{a}}$ \\
1978 & 4028 & \\
1984 & 6904 & $2,800,000$ \\
1986 & 8046 & $6,576,000$ \\
1988 & 9500 & $7,800,000$ \\
& & $9,500,000^{\mathrm{b}}$
\end{tabular}

Average Increase per Year:

1978-84

$1984-86$

$1986-88$

\section{9}

571

777
679,000

612,000

850,000

aSource: National Center for Employee Ownership (Oakland, CA)

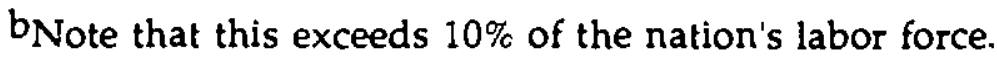

year-end 1988, there were 9500 ESOPs in existence covering 9.5 million workers. The number of new plans established in 1985 and 1986 (591 per year) was $19 \%$ higher than the average over the six years ending in 1984. And the number of new plans established in 1987 and 1988 ( 727 per year) was 27\% higher than 1985 and 1986. Moreover, an estimated 500 additional plans were established in the first four months of 1989 alone.

The U.S. General Accounting Office estimates that of the 6904 ESOPs at year-end 1984, only 4174 were still active. Approximately $90 \%$ of these plans were tax-credit ESOPs. Total assets in ESOPs at year-end 1984 were $\$ 19$ billion, of which $\$ 15$ billion were in tax-credit ESOPs ( $\$ 2,300$ per covered employee) and $\$ 4$ billion were in other ESOPs ( $\$ 5,700$ per covered employee).

Although it was the 1984 Tax Act that introduced the interest income exemption for qualified ESOP loans and deductibility of dividends paid out to employees, ESOP activity accelerated more quickly following the 1986 Act. The 1986 Act contained a number of ESOP and non-ESOP provisions that affected the desirability of ESOPs, to which we alluded earlier.

Since 1986, leveraged ESOPs in particular have exploded in economic significance. According to the National Center for Employer Ownership, new ESOP borrowings grew from $\$ 1.2$ billion in 1986 to $\$ 5.5$ billion in 1987 and $\$ 6.4$ billion in 1988. In addition, based on our analysis of disclosures available 
through the Dow Jones News Retrieval Service, plans to undertake more than $\$ 9$ billion of ESOP borrowings were announced during 1989 through May 10 alone!35 It is perhaps not surprising, therefore, that on June 6, 1989, Dan Rostenkowski, as chairman of the House Ways and Means Committee, introduced legislation to repeal the $50 \%$ interest exemption on ESOP loans. While this proposal is prompted by concerns over revenue losses to the U.S. Treasury, our analysis suggests that this concern may be misplaced. We have argued that takeover defense considerations are likely to have dominated. It is interesting to note that another batch of new ESOPs were hurriedly introduced by dozens of companies following the Rostenkowski proposal in an attempt to beat the new effective date for any adverse tax changes that might result from the passage of legislation. 36

\section{Summary}

An ESOP is an interesting organizational vehicle. Its main advantages over other forms of compensation are that it allows the corporation to obtain a below-market-rate-of-interest loan and that dividends on common stock are tax deductible if they are paid to ESOP participants. In the limit $(100 \%$ employee ownership), the corporate tax theoretically can be eliminated, although as a practical matter, gutting the corporate tax is impossible even with $100 \%$ employee ownership. And depending upon the circumstances, another great cost or benefit is its effectiveness as a defensive weapon. This is a cost when entrenchment allows existing management to secure private gain at the expense of shareholders and when a transfer of control over managerial decision rights to a more efficient group is prevented. It is a benefit, however, to the extent such protection from an outside bid promotes investment by employees in firm-specific capital that improves employee performance. Another important disadvantage of an ESOP is possible distortions in incentive compensation arrangements.

As if so often the case in public policy debates, the analysis to date of tax and nontax factors in the use of ESOPs has failed to consider the alternative institutional arrangements that are displaced by ESOPs. We have attempted to repair that omission here, and in so doing, we find ESOPs lacking in magic for their corporate sponsors along both tax and incentive dimensions, except perhaps in closely-held businesses. With these usual suspects rounded up, we are left with the creation of impediments to changes in corporate control as the prime motivation for ESOPs.

\footnotetext{
${ }^{35}$ We are grateful to Karen Wruck for assistance in securing these announcement data.

36Pensions and Investment Age Magazine, July 24, 1989.
} 


\section{$\underline{\text { References }}$}

Auerbach, Alan J., 1983, Taxation, Corporate Financial Policy and the Cost of Capital, Journal of Economic Literature Vol. 21 (September), pp. 905-40.

Bader, Lawrence N. and Jenny A. Hourihan, 1989a, The Investor's Guide to ESOP Loans (Salomon Brothers), (March).

Bader, Lawrence N. and Jenny A. Hourihan, 1989b, Financial Executives Guide to ESOPs: 1989 Update (Salomon Brothers), (May).

Blasi, Joseph R., 1988, Employee Ownership: Revolution or Ripoff? (Ballinger).

Conte, Michael A. and Jan Svejnar, 1989, The Performance Effects of Employee Ownership Plans, Working Paper Brookings Institution (March).

Cooper, Joseph E., 1989, Employee Stock Ownership Plans and Economic Efficiency, Working Paper, Harvard University, (March).

Forbes, Daniel, The Controversial ESOP Pension, 1986, Dun's Business Month (November), pp. 40-41.

Freiman, Howard A., 1989, Understanding Leveraged ESOP Economics (Fidelity Management Trust Company), (June).

Holmstrom, Bengt, 1978, Moral Hazard and Observability, Bell Iournal of Economics (Spring), pp. 74-91.

Jensen, Michael C., 1986, The Agency Cost of Free Cash Flow: Corporate Finance and Takeovers, American Economic Review, Vol. 76, No. 2 (May).

Jensen, Michael C., 1989, Capital Markets, Organizational Innovation, and Restructuring, Working Paper, Harvard Business School (January).

Kaplan, Steven, 1989, ESOP Notes, personal correspondence, (March 31).

Lambert, Richard A. and David F. Larcker, 1987, An Analysis of the Use of Accounting and Market Measures of Performance in Executive Compensation Contracts, Journal of Accounting Research (Supplement), pp. 85-125. 
Marsh, Thomas R. and Dale E. McAllister, 1981, ESOPs Tables: A Survey of Companies with Employee Stock Ownership Plans, Journal of Corporation Law (Spring), pp. 551-623.

Merrill Lynch, 1988, Employee Stock Ownership Plans, (October).

Miller, Merton H., 1977, Debt and Taxes, Lournal of Finance, Vol. 32 (May), pp. 261-75.

Patard, Richard J., 1985, Employee Stock Ownership in the 1970s, Employee Ownership - A Reader (National Center for Employee Ownership), p. 58.

Scholes, Myron S. and Mark A. Wolfson, 1988, The Cost of Capital and Changes in Tax Regimes, in Uneasy Compromise: Problems of a Hybrid Income-Consumption Tax edited by Aaron, Galper and Pechman, Brookings Institution, pp. 157-194.

Scholes, Myron S. and Mark A. Wolfson, 1989, Converting Corporations to Partnerships through Leverage: Theoretical and Practical Impediments, in Taxes and Corporate Restructurings, edited by John B. Shoven, Brookings Institution (forthcoming).

Scholes, Myron S. and Mark A. Wolfson, 1990, Taxes and Business Strategy: A Global Planning Approach (Prentice Hall), (forthcoming).

Shackleford, Douglas A., 1988, The Tax Incidence of the Interest Income Exclusion in Leveraged Employee Stock Ownership Plans, Working Paper, University of Michigan, (August).

Shearman and Sterling, 1989, ESOPs: What They Are and How They Work, (January).

Stiglitz, Joseph E., 1973, Taxation, Corporate Financial Policy, and the Cost of Capital, Iournal of Public Economics, 2, pp. 1 -34.

U.S. Government Accounting Office, 1986, Employee Stock Ownership Plans, GAO-PEMD-86-4BR, (February). 